\title{
Mortality in Acute Arterial Mesenteric Ischemia: A Single-Center Experience
}

\author{
Akut Arteryel Mezenterik İskemide Mortalite: Tek Merkez Deneyimi \\ Guner Cakmak, Kayhan Ozdemir, Baris Mantoglu, Merve Yiğit, Ugur Can Dulger
}

Sakarya University Research and Educational Hospital, Department of General Surgery, Sakarya Turkey

\author{
Yazışma Adresi / Correspondence: \\ Kayhan Özdemir \\ Şrinevler Mahallesi Adnan Menderes Caddesi Sağllk Sokak No:195 / 54100 Adapazarı Sakarya. \\ T: +90 $5323378855 \quad$ E-mail : Drkayhan1@gmail.com \\ Geliş Tarihi / Received : 04.06.2021 Kabul Tarihi / Accepte: 27.08.2021 \\ Orcid : \\ Guner Cakmak https://orcid.org/0000-0003-4040-4635 \\ Kayhan Ozdemir https://orcid.org/0000-0002-8041-198X \\ Baris Mantoglu https://orcid.org/0000-0002-2161-3629 \\ Merve Yigit https://orcid.org/0000-0001-5217-9629 \\ Ugur Can Dulger https://orcid.org/0000-0001-5476-715X \\ ( Sakarya Tip Dergisi / Sakarya Med J 2021, 11(3):601-607) DOI: 10.31832/smj.947804
}

\footnotetext{
Öz

Objective Acute mesenteric ischemia (AMI) is a life-threatening pathology that often requires urgent surgical intervention. It is frequently faced in elderly patients. Despite advances in the diagnosis of AMI morbidity, and mortality rates are still high. The presence of comorbidities delayed surgical intervention due to diagnostic difficulties, and in most cases, older patients with heart problems may be remarkable factors for higher mortality rates. Diagnostic challenges are tried to be overcome with both imaging methods and laboratory findings. Unfortunately, to date, no clear laboratory parameters have been described in diagnosing or predicting mortality of mesenteric ischemia. In our study, we aimed to evaluate the relationship between biochemical markers and mortality in AMI.

Materials The patients diagnosed with acute arterial mesenteric ischemia between the dates 2010-2019 were enrolled in the study. Demographic characteristics, diagnostic and Methods biochemical parameters (lymphocyte, neutrophil, albumin, C-reactive protein, lactate, lactate dehydrogenase, Di-Dimer, troponin, white blood count, platelet, fibrinogen, creatine kinase-MB) levels, as well as comorbidities of the patients, were evaluated.

Results A total of 149 patients was enrolled in the study, with a mean age of 66.11 . In the non-survivor group, neutrophil, RDW, lactate, DDM, Fibrinogen, and CK-MB levels, furthermore albumin levels were defined as significantly elevated in the survivor group $(\mathrm{p}<0.05)$. Hypertension was the major comorbidity by far in both groups.

Conclusion High levels of fibrinogen, lactate, DDM, CK-MB levels and low levels of albumin levels may be predictors of mortality in mesenteric ischemia.

Keywords Mesenteric ischemia; Mortality; Predictive factors

Amaç Akut mezenterik iskemi (AMI), sıklıkla acil cerrahi müdahale gerektiren hayatı tehdit eden bir patolojidir. Yașlı hastalarda sıklikla karșılașllmaktadır. AMI tanısındaki gelișmelere rağmen morbidite ve mortalite oranları hala yüksektir. Komorbiditelerin varlı̆̆, tanısal zorluklar nedeniyle cerrahi müdahaleyi geciktirir ve genellikle kardiyak problemleri olan yașlı hastalar, daha mortal seyredebilirler. Gerek görüntüleme yöntemleri gerekse laboratuvar bulguları ile tanısal zorluklar aşılmaya çalșılmaktadır. Günümüzde halen mezenterik iskeminin mortalitesini teşhis etmek veya tahmin etmek için net bir laboratuvar parametresi tanımlanmamıștır.Çalșșmamızda AMI’de biyokimyasal belirteçlerin mortalite ile iliş̧kisini değerlendirmeyi amaçladık.

2010-2019 tarihleri arasında akut arteriyel mezenterik iskemi tanıs alan hastalar çalışmaya dahil edildi. Demografik özellikler, tanısal biyokimyasal parametreler (lenfosit, nötrofil, albümin, C-reaktif protein, laktat, laktat dehidrojenaz, D-Dimer, troponin, beyaz kan sayımı, trombosit, fibrinojen, kreatin kinaz-MB) seviyeleri ve ayrıca komorbiditeler değerlendirildi.

Bulgular

Çalışmaya yaş ortalamast 66.11 olan toplam 149 hasta alınd. Mortal seyirli grupta nötrofil, RDW, laktat, DDM, Fibrinojen ve CK-MB seviyeleri, ayrica albümin seviyeleri hayatta kalan grupta anlamlı olarak yüksek olarak tanımlandı $(p<0.05)$. Her iki grupta da açık ara en önemli komorbidite hipertansiyondu.

Yüksek fibrinojen, laktat, DDM, CK-MB seviyeleri ve düșük albümin seviyeleri mezenterik iskemide mortaliteyi saptamada prediktiffaktörler olabilirler. 


\section{INTRODUCTION}

Acute mesenteric ischemia (AMI) is a life-threatening disease that progresses with the occlusion of the mesenteric vessels that feed the intestines, which is often misdiagnosed and requires urgent surgical intervention. ${ }^{1}$ The incidence of AMI increases with age, and while the mean age of onset was 67 years, there was no difference in incidence between men and women., ${ }^{2,3}$ The most common causes of impairment of blood flow to the intestine are mesenteric vascular insufficiency due to underlying causes such as atherosclerosis, mesenteric artery embolism, vasospasm, and mesenteric vein thrombosis. ${ }^{4,5}$ The duration of ischemia, degree of mesenteric artery occlusion, and rate of collateral flow are factors that determine bowel injury after acute arterial occlusion. ${ }^{6}$ Four main etiological factors can be mentioned in AMI, and $75 \%$ of these are arterial occlusions (50\% arterial embolism, $25 \%$ arterial thrombosis). ${ }^{1-3}$ The most leading reason for the delay in diagnosis of AMI is the rise of acute abdominal examination findings in the last period of the disease. Despite advanced diagnostic methods, the critical diagnostic step is to suspect that the patient may have AMI. Although the American Society of Gastroenterology practice guidelines set angiography as the gold standard in mesenteric ischemia, availability to this intervention may not be appropriate in every hospital. ${ }^{7}$ The most vital advantage of catheter angiography is that it can favorably affect mortality and morbidity, as well as the surgical requirement of the patient, by recanalization of the occluded artery in patients to whom can be applied and detected at an early stage of the disease. Nevertheless, in recent years, computed tomography angiography (CTA) has been replaced the role of catheter angiography, especially in terms of faster application and as a less invasive method in the diagnose of AMI. ${ }^{1,8}$

Surgical intervention is the crucial part of the treatment of AMI. The results of surgical intervention, which can be performed without the signs of peritonitis, can be promising. In the surgical approach, while trying to ensure the continuity of the gastrointestinal system by resection of the ischemic bowel and observing the continuity of the blood flow, this patient group should be followed up in intensive care in the post-operative period. ${ }^{9}$

In addition to the radiological diagnosis of AMI, the contribution of laboratory data in this process may be valuable in determining the prognosis and severity of the patient. Nevertheless, to date, the specificity of any laboratory parameter or group cannot be mentioned in the prognosis or diagnosis of AMI. ${ }^{3,10}$ Biomarkers such as L-lactate, D-dimer, leukocyte, $C$ reactive protein (CRP), and NLR levels are the frequently utilized laboratory parameters that can be taken into account.

This retrospective study aims to evaluate the effectiveness of preoperative biochemical parameters in predicting mortality and survival in patients diagnosed with AMI.

\section{MATERIAL and METHODS}

Our study was carried out in accordance with the Declaration of Helsinki with the approval of Sakarya University Faculty of Medicine Non-Invasive Clinical Research Ethics Committee dated 29.01.2021 and numbered E-71522473050.01.04.32179-296. The files of patients who were diagnosed with AMI (arterial occlusion) between January 2010 and June 2019 and underwent surgical intervention were retrospectively analyzed. The diagnosis of AMI was based on clinical laboratory and CTA findings. All patients having the signs of peritonitis underwent surgery. Patients with venous ischemia defined in imaging methods and cases with complete root occlusion of the superior mesenteric artery were excluded from the study. Demographic characteristics, diagnostic biochemical parameters (lymphocyte, neutrophil, albumin, CRP, lactate, lactate dehydrogenase (LDH), Di-Dimer, troponin, white blood count (WBC), platelet, fibrinogen, creatine kinase-MB) levels, as well as comorbidities of the patients, were evaluated.

\section{Statistical Analysis}

SPSS (Statistics Package for Social Sciences, SPSS Inc., Chi- 
cago, IL, USA) Windows 11 program was used to statistically analyze the results of the study. Kolmogorov-Smirnov test was used for the compatibility of the normal distribution of the data. $\mathrm{P}<0.05$ values are considered significant for all variables.

\section{RESULTS}

A total of 149 patients was enrolled in the study, with a mean age of $66.11 \pm$ in the survivor group (SG) and 66.79 \pm in the non-survivor group (NSG). One hundred sixteen patients were survived (77.9\%). There was no statistically significant difference in terms of gender between the groups. (Table 1).

Table 1. Frequency distribution of the gender and age of the patients according to their life status.

\begin{tabular}{|l|c|c|c|c|}
\hline & \multicolumn{2}{|c|}{$\begin{array}{c}\text { Survivor } \\
(\mathrm{n}=116 ; 77,9 \%)\end{array}$} & \multicolumn{2}{c|}{$\begin{array}{c}\text { Non-survivor } \\
(\mathrm{n}=33 ; 22,1 \%)\end{array}$} \\
\hline & $\mathrm{f}$ & $\%$ & $\mathrm{f}$ & $\%$ \\
\hline Male & 57 & 57,8 & 16 & 48,5 \\
\hline Female & 49 & 42,2 & 17 & 51,5 \\
\hline Sum & 116 & 100 & 33 & 100 \\
\hline Mean age & \multicolumn{3}{|c|}{66,11} & \multicolumn{2}{c|}{66,79} \\
\hline $\begin{array}{l}\text { Highest } \\
\text { age }\end{array}$ & \multicolumn{3}{|c|}{97} & \multicolumn{2}{c|}{89} \\
\hline Lowest age & \multicolumn{2}{|c|}{19} & \multicolumn{3}{c|}{} \\
\hline
\end{tabular}

When patients' data on comorbid diseases are evaluated, it is figured out that hypertension (HT) ranks first in both the SG $(31.0 \%$ and the NSG $(21.2 \%)$ in terms of the most common comorbidities. Although the SG generally has more comorbidities, diabetes mellitus (DM) is the second most common disease with $7.8 \%$ after HT. On the other hand, when the data of the SG are examined, DM comes second with $9.1 \%$, and COPD comes third with $6.1 \%$ respectively (Table 2 ).
Table 2. Frequency distribution of comorbid diseases of patients according to their life status.

\begin{tabular}{|l|c|c|c|c|}
\hline & \multicolumn{2}{|c|}{$\begin{array}{c}\text { Survivor } \\
(\mathrm{n}=116)\end{array}$} & \multicolumn{2}{c|}{$\begin{array}{c}\text { Non-survi- } \\
\text { vor(n=33) }\end{array}$} \\
\hline & $\mathrm{f}$ & $\%$ & $\mathrm{f}$ & $\%$ \\
\hline Alzheimer & 5 & 4,3 & - & - \\
\hline Arhythmia & 1 &, 9 & - & - \\
\hline Atrial fibrillation & 3 & 2,6 & 1 & 2,6 \\
\hline Benign prostatic hypertrophy & 1 &, 9 & 1 & 3,0 \\
\hline Buerger & 1 &, 9 & - & - \\
\hline Crohn & 1 &, 9 & - & - \\
\hline Diabetes mellitus & 9 & 7,8 & 3 & 9,1 \\
\hline Deep vein thrombosis & 1 &, 9 & - & - \\
\hline Epilepsy & 1 &, 9 & - & - \\
\hline Hepatitis B & - & - & - & - \\
\hline Hepatitis C & - & - & - & - \\
\hline Hypothyroidism & 1 &, 9 & - & - \\
\hline Hypertension & 36 & 31,0 & 7 & 21,2 \\
\hline Coronary artery disease & 4 & 3,4 & 1 & 3,0 \\
\hline Chronic renal failure & 3 & 2,6 & 2 & 2,6 \\
\hline $\begin{array}{l}\text { Chronic obstructive pulmo- } \\
\text { nary disease }\end{array}$ & 7 & 6,0 & 2 & 6,1 \\
\hline Colon cancer & 2 & 1,7 & - & - \\
\hline Heart failure & 4 & 3,4 & - & - \\
\hline Parkinson's disease & 2 & 1,7 & - & - \\
\hline Kidney failure & 2 & 1,7 & 1 & 3,0 \\
\hline Cerebrovascular disease & & & - & - \\
\hline
\end{tabular}

In the non-survivor group, neutrophil, RDW, lactate, DDM, Fibrinogen, and CK-MB levels, furthermore albumin levels were defined as significantly elevated in the survivor group $(\mathrm{p}<0.05)$ (Table 3$)$.

The age and gender of the patients were compared according to the survival status, and it ascertained that there was no statistically significant difference (Table 4). Considering the surviving patients in the context of the age category, it was noticed that $39.7 \%$ of the survivor patients were under 65 years, and $60.3 \%$ were 65 years aged and over. In addition, it has been noted that $39.4 \%$ of the non-survivor patients are below 65 years, and $60.6 \%$ are 65 years aged and higher. However, there was no statistically significant difference between groups (Table 5). 
Sakarya Med J 2021;11(3):601-607

CAKMAK et al., Acute Arterial Mesenteric Ischemia: Our experience

Table 3. Comparison results of Lymphocyte, Neutrophil, RDW, Albumin, CRP, Lactate, DDM, WBC, PLT, Fibrinogen and Ck-Mb Parameters of the Patients According to Their Life Status

\begin{tabular}{|c|c|c|c|c|c|c|}
\hline & Status & $\mathrm{n}$ & $\begin{array}{c}\text { Mean value } \\
\text { Rank Average }\end{array}$ & Rank Sum & $\mathrm{U}$ & $\mathrm{p}$ \\
\hline \multirow{2}{*}{ Lymphocyte } & Survivor & 116 & 76,89 & 8919,50 & \multirow{2}{*}{1694,50} & \multirow{2}{*}{,320 } \\
\hline & Non-Survivor & 33 & 68,35 & 2255,50 & & \\
\hline \multirow{2}{*}{ Neutrophil } & Survivor & 116 & 70,83 & 8216,00 & \multirow{2}{*}{1430,00} & \multirow{2}{*}{,030 } \\
\hline & Non-Survivor & 33 & 89,67 & 2959,00 & & \\
\hline \multirow{2}{*}{$\mathrm{Rdw}$} & Survivor & 116 & 72,27 & 8383,00 & \multirow{2}{*}{1597,00} & \multirow{2}{*}{, 150 } \\
\hline & Non-Survivor & 33 & 84,61 & 2792,00 & & \\
\hline \multirow{2}{*}{ Albumin } & Survivor & 116 & 80,34 & 9319,00 & \multirow{2}{*}{1295,00} & \multirow{2}{*}{, 010 } \\
\hline & Non-Survivor & 33 & 56,24 & 1856,00 & & \\
\hline \multirow{2}{*}{ Crp } & Survivor & 116 & 71,81 & 8330,50 & \multirow{2}{*}{1544,50} & \multirow{2}{*}{,090 } \\
\hline & Non-Survivor & 33 & 86,20 & 2844,50 & & \\
\hline \multirow{2}{*}{ Lactate } & Survivor & 116 & 65,88 & 7642,00 & \multirow{2}{*}{856,00} & \multirow{2}{*}{, 000} \\
\hline & Non-Survivor & 33 & 107,06 & 3533,00 & & \\
\hline \multirow{2}{*}{$\mathrm{D}-\mathrm{dm}$} & Survivor & 68 & 38,47 & 2616,00 & \multirow{2}{*}{270,00} & \multirow{2}{*}{000} \\
\hline & Non-Survivor & 32 & 76,06 & 2434,00 & & \\
\hline \multirow{2}{*}{ Troponin } & Survivor & 69 & 42,20 & 2912,00 & \multirow{2}{*}{497,00} & \multirow{2}{*}{000} \\
\hline & Non-Survivor & 31 & 68,97 & 2138,00 & & \\
\hline \multirow{2}{*}{$\mathrm{Wbc}$} & Survivor & 116 & 76,89 & 8919,50 & \multirow{2}{*}{1694,50} & \multirow{2}{*}{320} \\
\hline & Non-Survivor & 33 & 68,35 & 2255,50 & & \\
\hline \multirow{2}{*}{ Fibrinogen } & Survivor & 72 & 76,22 & 8841,50 & \multirow{2}{*}{485,00} & \multirow{2}{*}{000} \\
\hline & Non-Survivor & 33 & 70,71 & 2333,50 & & \\
\hline \multirow{2}{*}{ Ck_Mb } & Survivor & 74 & 43,24 & 3113,00 & \multirow{2}{*}{814,00} & \multirow{2}{*}{, 010} \\
\hline & Non-Survivor & 32 & 74,30 & 2452,00 & & \\
\hline
\end{tabular}

Table 4. Statistical results of the gender of the patients according to their life status

\begin{tabular}{|c|c|c|c|c|c|c|}
\hline & & & & & & \\
\hline & & & Male & Female & $X^{-}$ & $\mathrm{p}$ \\
\hline 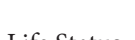 & Survivor & $\mathrm{n}$ & $67(57,8 \%)$ & $49(42,2 \%)$ & 80 & 0 \\
\hline & Non-Survivor & $\mathrm{n}$ & $16(48,5 \%)$ & $17(51,5 \%)$ & & \\
\hline
\end{tabular}

Tablo 5. Statistical results of the patients' ages according to their life status

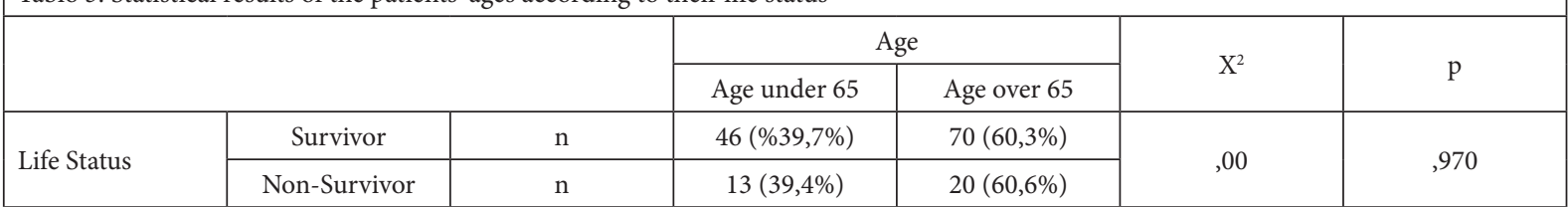




\section{DISCUSSION}

AMI was first described in detail in the 15th century.11 Risk factors affecting mortality in acute mesenteric ischemia have not been studied much, and published studies are incompatible with each other. ${ }^{12,13}$ AMI is a low volume emergency, with an incidence of 0.63 per 100,000 in Europe and 1 in 1000 hospitalized patients in Europe and the United States. ${ }^{14,15}$ Even there is no gender difference in AMI a handful of studies indicate that $70 \%$ proportion of the patients are female., ${ }^{2,15}$ The majority of cases in AMI arise in patients of advanced age and especially in patients with additional cardiovascular diseases. Hypertension and diabetes mellitus, which predispose cardiovascular comorbidities such as atrial fibrillation, ischemic heart disease, and coronary artery disease, can be mentioned as the leading reasons for AMI., ${ }^{2,14,16}$ When we examine our patient groups, we detected that the average age of AMI experience was close to the literature average (Table 1). When the previous studies are evaluated, particularly cardiovascular diseases come to the fore however, hypertension and diabetes mellitus, which are the main reasons for the emergence of cardiovascular disorders, were ascertained to be significant comorbidity for AMI in both the survivor and the non-survivor group (Table 2). Interestingly, while comorbidities were detected in several diverse groups in the survivor group, the non-survivor group consisted of a limited group of diseases. Thereby, beyond the variety and multiplicity of comorbidity in AMI, the presence of cardiovascular pathologies can be mentioned as chief etiologic factors on mortality (Table 2).

Although laboratory results are inconclusive, the existence of nonidentical values may assist clinical suspicion. A specific biomarker for the early diagnosis of AMI has not yet been defined. ${ }^{14,17}$ Acidosis, amylase, urea, creatinine, and increased leukocyte count have been associated with mortality in various studies. ${ }^{12,15,16,18-20}$ In addition, the levels of D-dimer, which is the enzymatic product of intravascular coagulation, and lactate can be found to be high even if not specific for AMI. ${ }^{21}$ In a large meta-analysis in which biomarkers have been evaluated to date has been emphasized that amylase, leukocyte count, LDH are not fitting tests for the diagnosis of AMI due to the low predictive value of intestinal ischemia. ${ }^{1,3,22}$ In this current study, a key role may be referred to the biomarkers we checked due to selecting the same type of AMI group (arterial occlusion). Thus, the determined parameters can be more decisive. In our study, we found that the percentage of neutrophils, RDW, Lactate, D-dimer, troponin, fibrinogen, and CK-MB levels were significantly higher in the non-survivor group, and similar results are available in the literature (Table 3, Figure 1,2,3). Albumin levels were statistically elevated in the survivor group (Figure 1). Although not surprising, average values of albumin levels contribute significantly to the recovery of many surgical diseases but have never been described for AMI.

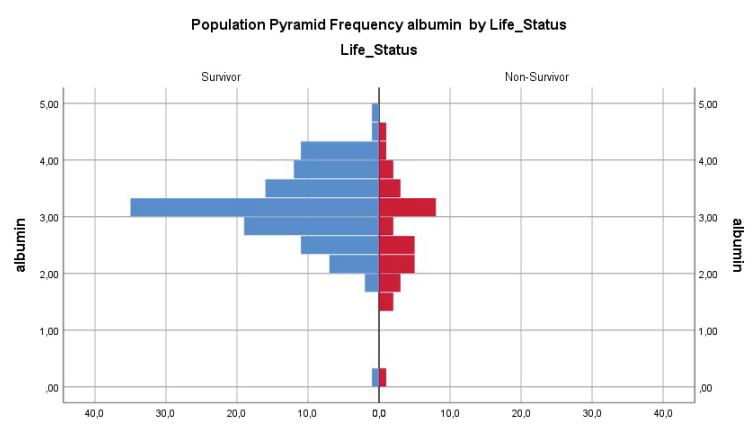

Figure 1 : Population pyramid of frequency between life status and albumin

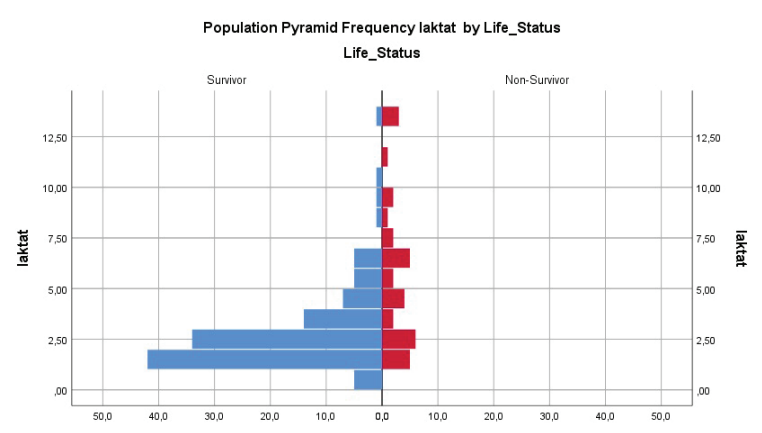

Figure 2 : Population pyramid frequency between life status and lactate 


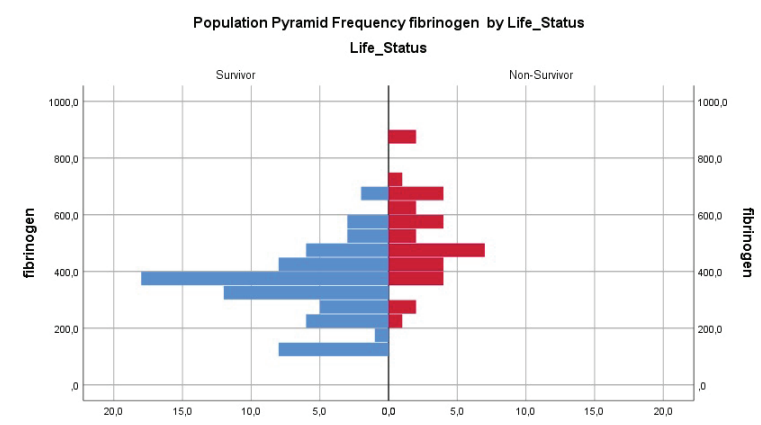

Figure 3 : Population pyramid frequency between life status and fibrinogen

The weakness of our study is that although it is not possible to design a prospective study on this subject, it is a retrospective review as well as a single-center experience. The fact that the number of patients included in the research is relatively satisfactory, so the results of the study are explicit and may contribute to the literature.

AMI is a disease frequently discerned in the elderly, and despite advances in diagnosis and treatment, morbidity moreover mortality rates are still high. In our series of 149 patients, we observed that high levels of lactate, fibrinogen, DDM, CK-MB and low albumin levels at the time of admission had an increasing effect on mortality. Based on these findings, we speculate that lactate, fibrinogen, and albumin levels at presentation may be prognostic factors in acute mesenteric ischemia.

Our study was carried out in accordance with the Declaration of Helsinki with the approval of Sakarya University Faculty of Medicine Non-Invasive Clinical Research Ethics Committee dated 29.01.2021 and numbered E-71522473-050.01.04.32179-296. The files of patients who were diagnosed with AMI (arterial occlusion) between January 2010 and June 2019 and underwent surgical intervention were retrospectively analyzed. 
Sakarya Med J 2021;11(3):601-607

CAKMAK et al., Acute Arterial Mesenteric Ischemia: Our experience

\section{References}

1. Bala M, KashukJ, Moore EE, Kluger Y, Biffl W, Gomes CA, et al. Acute mesenteric ischemia: guidelines of the World Society of Emergency Surgery. World J Emerg Surg. 2017; 12:38.

2. Cudnik MT, Darbha S, Jones J, Macedo J, Stockton SW HB. The diagnosis of acute mesenteric ischemia: A systematic review and meta-analysis. Acad Emerg Med. 2013; 20(11):10871100.

3. Memet $O$, Zhang L SJ. Serological biomarkers for acute mesenteric ischemia. Ann Transl Med. 2019;7(16):394.

4. Kougias P, Lau D, El Sayed HF, Zhou W, Huynh TT, Lin PH. Determinants of mortality and treatment outcome following surgical interventions for acute mesenteric ischemia. J Vasc Surg. 2007;46(3):467-474.

5. Stamatakos $M$, Stefanaki $C$, Mastrokalos D, Arampatzi H, Safioleas $P$, Chatziconstantinou $C$, et al. Mesenteric ischemia: still a deadly puzzle for the medical community. Tohoku J Exp Med. 2008;216(3):197204.

6. Kaleya RN BS. Acute mesenteric ischemia. Crit Care Clin. 1995;11(2):479-512.

7. Brandt LJ BS. AGA technical review on intestinal ischemia. American Gastrointestinal Association. Gastroenterology. 2000; 118(5):954-968.

8. Kirkpatrick ID, Kroeker MA GH. Biphasic CT with mesenteric CT angiography in the evaluation of acute mesenteric ischemia: initial experience. Radiology. 2003; 229(1):91-98.

9. Oldenburg WA, Lau LL, Rodenberg TJ, Edmonds HJ BC. Acute mesenteric ischemia: a clinical review. Arch Intern Med. 2004; 164(10):1054-1062.

10. Luther B, Mamopoulos A, Lehmann C KE. The Ongoing Challenge of Acute Mesenteric Ischemia. Visc Med. 2018;34(3):217-213.

11. Boley SJ, Brandt LJ SR. History of mesenteric ischemia. The evolution of a diagnosis and management. Surg Clin North Am. 1997;77(2):275-288.

12. Schwartz LB GB. Mesenteric ischemia. Surg Clin North Am. 1997;77:275-5002.
13. Mamode N, Pickford I LP. Failure to improve outcome in acute mesenteric ischaemia: seven-year review. Eur J Surg. 1999;165(3):203-208.

14. Tilsed JV, Casamassima A, Kurihara H, Mariani D, Martinez I, Pereira J, et al. ESTES guidelines: acute mesenteric ischaemia. Eur J Trauma Emerg Surg. 2016;42(2):253-270.

15. Clair DG BJ. Mesenteric Ischemia. N Engl J Med. 2016;374(10):959-968.

16. Acosta S. Epidemiology of mesenteric vascular disease: clinical implications. Semin Vasc Surg. 2010;23(1):4-8

17. Treskes N, Persoon AM, van Zanten ARH. Diagnostic accuracy of novel serological biomarkers to detect acute mesenteric ischemia: a systematic review and meta-analysis. Intern Emerg Med. 2017;12(6):821-836.

18. Huang HH, Chang YC, Yen DH, Kao WF, Chen JD, Wang LM, et al. Clinical factors and outcomes in patients with acute mesenteric ischemia in the emergency department. J Chin Med Assoc. 2005;68(7):299-306.

19. Acosta-Merida MA, Marchena-Gomez J, Hemmersbach-Miller M, Roque-Castellano C, Hernandez-Romero JM. Identification of risk factors for perioperative mortality in acute mesenteric ischemia. World J Surg. 2006;30(8):1579-1585.

20. Aliosmanoglu I, Gul M, Kapan M, Arikanoglu Z, Taskesen F, Basol O AM. Risk factors effecting mortality in acute mesenteric ischemia and mortality rates: a single center experience. Int Surg. 2013;98(1):76-81.

21. Mamode N, Pickford I LP. Failure to improve outcome in acute mesenteric ischaemia: seven-year review. Eur J Surg. 1999;165(3):203-208.

22. Derikx JP, Schellekens DH AS. Serological markers for human intestinal ischemia: A systematic review. Best Pr Res Clin Gastroenterol. 2017;31(1):69-74. 